\title{
Functioning of South Moravian Floodplain Forests (Czech Republic) in Forest Environment Subject to Natural and Anthropogenic Change
}

\author{
Emil Klimo, ${ }^{1}$ Jiří Kulhavý, ${ }^{1}$ Alois Prax,${ }^{1}$ Ladislav Menšík, ${ }^{1}$ \\ Pavel Hadaš, ${ }^{2}$ and Oldřich Mauer ${ }^{3}$ \\ ${ }^{1}$ Department of Forest Ecology, Mendel University in Brno, Zemedelska 3, 61300 Brno, Czech Republic \\ ${ }^{2}$ Data Processing, Ořechovka 1727, 69662 Strážnice, Czech Republic \\ ${ }^{3}$ Department of Silviculture, Mendel University in Brno, Zemedelska 3, 61300 Brno, Czech Republic
}

Correspondence should be addressed to Ladislav Menšík; ladislav.mensik@mendelu.cz

Received 18 February 2013; Revised 18 April 2013; Accepted 19 April 2013

Academic Editor: Leon Bren

Copyright ( 2013 Emil Klimo et al. This is an open access article distributed under the Creative Commons Attribution License, which permits unrestricted use, distribution, and reproduction in any medium, provided the original work is properly cited.

\begin{abstract}
South Moravian floodplain forests at the confluence of the Morava and Dyje Rivers, which are related to the floodplain forests of Austria and Slovakia to a considerable degree, have been strongly affected by changes in forest environment caused by natural and anthropogenic impacts. The dominant change factors encompassed changes in the 12-14th centuries resulting in the formation of a flooded alluvium and a significant transition of hardwood floodplain to softwood floodplain. Their further development was affected particularly by forestry activities, and they saw a gradual transformation into hardwood floodplain forests with dominant species of oak, ash, hornbeam, and others. The primary impact in the 20th century was stream regulation and the construction of three water reservoirs, which resulted predominantly in changes in the groundwater table. Response to these changes was registered particularly in the herb layer. The contemporary forest management adjusts to environmental changes and makes efforts to alleviate the negative impacts of previously implemented changes through restoration projects.
\end{abstract}

\section{Introduction}

The Czech Republic houses approximately 33,000 ha floodplain forests concentrated in four main sites (Figure 1) [1].

(1) South Moravia (Morava and Dyje Rivers) $-15,800$ ha,

(2) Litovelské Pomoraví-10,400 ha,

(3) the Odra River alluvium-600 ha,

(4) the Labe River alluvium-6,300 ha.

Over the course of time, South Moravian floodplain forests, situated in the alluvium of the lower reach of the Morava River and primarily at the confluence of the Morava and Dyje, have been subject to a complex evolution related to changes in landscape development and human impact (site no 1 in Figure 1.) The prevailing vegetation type is "Fraxino pannonical ulmetum" [2]. According to [3], several cold and dry glacial periods have alternated with warm and humid interglacial periods in the Quaternary over the past two million years. This is characterized by alternating gully erosion and accumulation stages and a gradual formation of today's landscape morphology. During these periods the landscape was gradually covered with vegetation, as the buried humus horizons attest to this. River gravels deposited in the conditions of the so-called rampaging river, under which the riverbed frequently changed its course within the entire floodplain. Later, river sands and sandy gravels were deposited in the streams of meandering rivers. These processes conditioned the resulting heterogeneity of alluvial cover. The youngest fine-grained deposits come in the form of alluvial silts and clays which level out river floodplains to their existing shape. These processes were interrupted, as humus horizons at different depths of the soil profile attest to. At the time of a relative stabilization of the natural conditions, first human settlements appeared in the Morava and Dyje alluvia. Poláček [4] states that in the period 8,000-6,000 BC sandy 


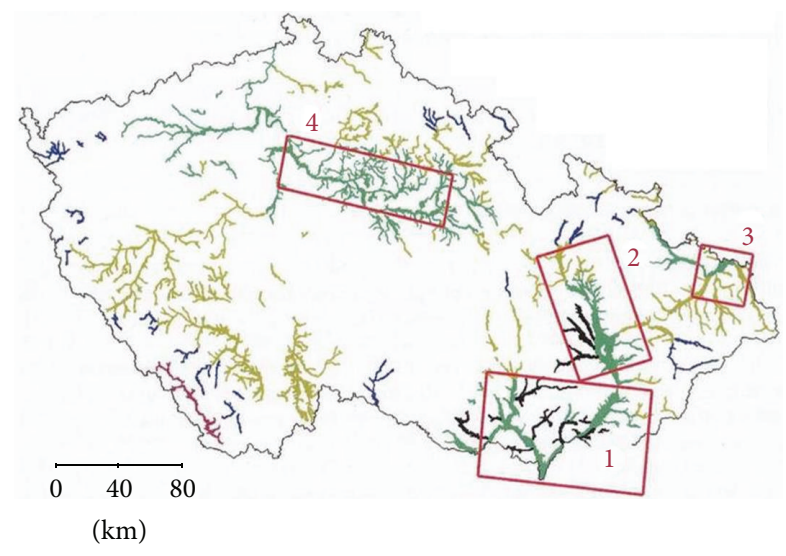

Figure 1: Distribution of floodplain forests in the Czech Republic [1].

islands in the river floodplain represented sought-after settlement areas for Mesolithic hunters and fishermen. Owing to massive colonization and forest felling, particularly in the early and late Bronze Ages (2000-750 BC), erosion intensified and the areas of herb growths consequently increased. An important milestone in the Morava and Dyje Rivers floodplain colonization was the arrival of Slavs in Moravia in the first third of the sixth century AD. Naturally, these tribes were attracted to the fertile areas along rivers. The river constituted a source of life, and the surrounding oak-hornbeam forests provided plenty of timber, game, and forest crops. The High Middle Ages (1250-1492 AD) saw a major change in the hydrological and geomorphological relationships in rivers which was accompanied by massive floods and a gradual levelling of the river floodplain by alluvial silts [4].

\section{Changes in Land Use}

As a result of changes in natural conditions, the species composition of floodplain forests gradually shifted towards the so-called softwood floodplain. Colonization of the submontane regions, massive deforestation, changes in land use, and a general devastation of the landscape all contributed to floods and the accompanying erosion. The origins of changes in land use in the Morava and Dyje River floodplains lie both in natural and anthropogenic factors, the latter eventually becoming dominant [5]. Provided a complex study of the changes in land use in her dissertation. Between 1836 and 1999 the total length of the Morava River decreased from $344.86 \mathrm{~km}$ to $268.02 \mathrm{~km}$. The most pronounced changes were recorded along the river's lower reach, in the area of the Lower Morava River Valley, where the course was shortened by $48 \mathrm{~km}$. This shortening accelerated the stream flow and decreased water seepage into the surrounding soil environment. Table 1 reveals that meadows were the most frequently represented form of land use in the 19th century. This changed radically in the 1950s, however, when meadows were gradually ploughed up and grazing in the floodplain was put to an end. Forests appear to be a highly stable component of the floodplain throughout the entire period. In this respect, however, the replacement of 1,400 ha of floodplain forests by water bodies (the Nové Mlýny Water Reservoirs) in the 1980s must be noted.

Generally it may be said, as [5] observes, that meadows and forests, that is, ecosystems of a high retention capacity, prevailed in the Morava River floodplain in the 19th century. Arable land was found on sites further from the river. Particularly the massive floods of 1997 showed that forest geobiocenoses and meadows are capable of retaining and slowing down the extreme water runoff to a certain degree.

The Early Middle Ages were characterized by prevailing communities of hardwood floodplain forests with oak, elm, and ash. These forests were considerably open and served as pastures as well. After pasture farming disappeared, individual oak stems often remained, under which stands of ash originated through natural regeneration, which later contributed to the establishment of nature reserves.

The evolution of floodplain forests on the lower reaches of the Morava and Dyje Rivers was influenced by land ownership as well. From this perspective, the Liechtenstein family played a historically significant role. Starting from 1249 they had gradually become the biggest landowners of both farm and forest land until their estate was confiscated by the state after World War 2. The Liechtensteins introduced amelioration measures which drained excessive water and resulted in a gradual transformation of the softwood floodplain forests into a floodplain with prevailing hardwood species, such as oak (Quercus robur L.), ash (Fraxinus excelsior L.; Fraximus angustifolia Vahl), or hornbeam (Carpinus betulus L.).

\section{Water Management Measures}

Apart from a high groundwater table, the basic characteristic which holds for all floodplain ecosystems is regular natural inundation by flooded rivers, usually in times of spring floods. South Moravian forests used to be thus affected by water from the Dyje, Kyjovka, and Morava Rivers, but regular floods in these rivers' lower reaches have long been a thing of the past. The last natural flood in the Dyje River took place in 1972 and in the Morava and Kyjovka Rivers in 1977. The elimination of natural flooding is a result of the construction of the Nové Mlýny Water Reservoirs on the Dyje River (1968-1988) and completed regulation of the rivers' lower reaches in the same period. On the one hand, this measure improved the living conditions of the local inhabitants and increased the safety of their activities, while on the other hand it had a highly adverse effect on the floodplain ecosystem. Floods occur at present as well, albeit in the form of disastrous events in the vegetation season, and always have a significantly negative impact on the floodplain forests, namely, their regeneration.

The completed regulation of the lower reaches of the Dyje and Morava Rivers in the 1970s and 1980s threatened the very existence of the floodplain forest complex. It was partly due to recessing of riverbeds in the channelized streams, followed by a drop in the groundwater table levels in forests by up to $1 \mathrm{~m}$ (Figure 2).

However, the biggest problem in the floodplain ecosystems was caused by the absence of regular inundation. 
TABLE 1: Land use in the Morava River floodplain [5].

\begin{tabular}{|c|c|c|c|c|c|c|c|c|}
\hline & \multicolumn{2}{|c|}{1836} & \multicolumn{2}{|c|}{1877} & \multicolumn{2}{|c|}{1953} & \multicolumn{2}{|c|}{$1999^{*}$} \\
\hline & $\mathrm{km}^{2}$ & $\%$ & $\mathrm{~km}^{2}$ & $\%$ & $\mathrm{~km}^{2}$ & $\%$ & $\mathrm{~km}^{2}$ & $\%$ \\
\hline Forests & 177.2 & 27.89 & 168.97 & 26.58 & 159.92 & 25.16 & 162.23 & 25.52 \\
\hline Meadows & 273.52 & 43.03 & 222.61 & 35.02 & 179.26 & 28.20 & 53.86 & 8.47 \\
\hline Pastures & 28.7 & 4.51 & 21.92 & 3.45 & 6.95 & 1.1 & $\mathbf{0}$ & 0.0 \\
\hline Arable land & 136.65 & 21.5 & 196.78 & 30.95 & 235.94 & 37.11 & 329.28 & 51.8 \\
\hline Gardens and orchards & 0.85 & 0.13 & 4.4 & 0.69 & 12.53 & 1.97 & 0.47 & 0.07 \\
\hline Settlements & 16.3 & 2.56 & 19.36 & 3.05 & 38.24 & 6.01 & 66.16 & 10.41 \\
\hline Transport routes & 0.39 & 0.06 & 0.85 & 0.13 & 2.06 & 0.321 & 2.24 & 0.35 \\
\hline Water areas & 2.02 & 0.32 & 0.81 & 0.13 & 0.8 & 0.13 & 21.46 & 3.38 \\
\hline Total & 635.7 & 100 & 635.7 & 100 & 635.7 & 100 & 635.7 & 100 \\
\hline
\end{tabular}

*The data are adopted from project "Restoration of the Ecological Continuum of the Morava River."

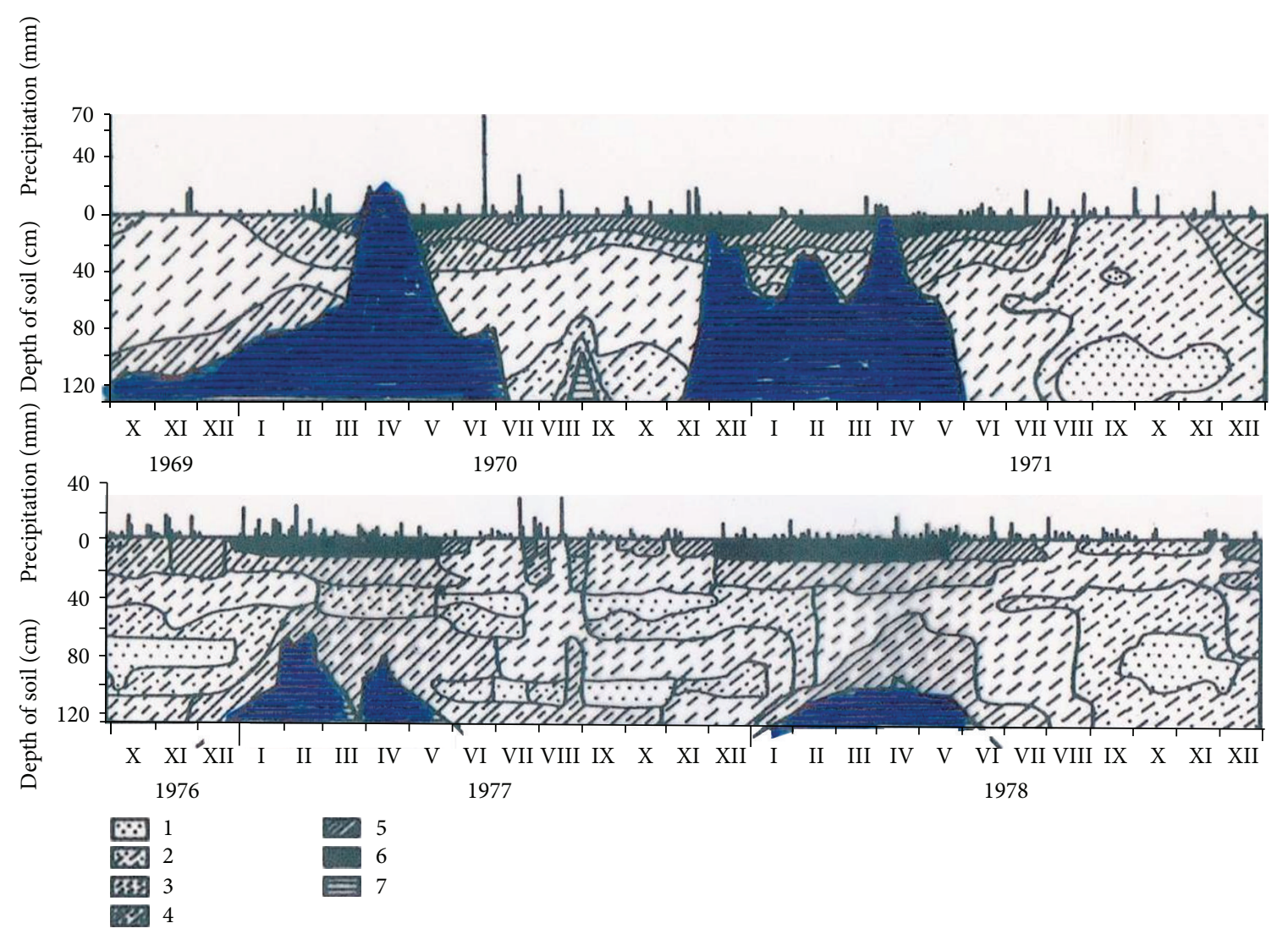

FIGURE 2: The dynamics of soil moisture (chronoisopleths) measured on research site in a period of floods (1969-1971) and in a period without floods (1976-1978). Soil moisture in percent by volume (1) 25-30, (2) 30-35, (3) 35-40, (4) 40-45, (5) 45-50, (6) 50-55, and (7) groundwater [7].

The floodplain forests began a slow transformation into a different, drier type of forests.

3.1. Development of Moisture Balance. An objective assessment of the development of abiotic conditions (temperatures and precipitation) in the floodplain forest ecosystem with respect to the assurance of sustainable management of these floodplain forests also involves the moisture balance. Calculation of moisture balance (MB) for a period 1851-2011 is based on a basic relation [8]. The basic relation was adjusted for the value of horizontal precipitation as follows:

$$
\mathrm{MB}=\left[\left(R_{a}+\mathrm{HP}\right)-R_{n}\right]-\left(\mathrm{ETP}_{a}-\mathrm{ETP}_{n}\right),
$$

where $R_{a}$ is monthly precipitation total in the given year in $\mathrm{mm} ; R_{n}$ is long-term precipitation total in the given month; $\operatorname{ETP}_{a}$ is monthly total potential evapotranspiration in the given year in $\mathrm{mm}$; $\operatorname{ETP}_{n}$ is long-term total potential evapotranspiration in the given month in $\mathrm{mm}$. The sum of moisture 
balance is calculated for the months of April through to September. Potential evapotranspiration (ETP) is derived by indirect method according to Thornthwaite [9].

The long-term monthly precipitation totals, average monthly air temperatures, and potential evapotranspiration in the area of floodplain forests are presented in Table 1. The moisture balance calculation also took into account fixed values of horizontal precipitation (HP) totals for stand microclimate, derived as an average of localities under study. The precipitation improves the total moisture balance. Development of moisture balance (MB) in the area of floodplain forests in 1851-2011 is illustrated in Figure 3 and Table 2.

It follows from Figure 3 that there are great changes occurring in the development of moisture balance between individual years. The changes reflect very markedly the temperature and precipitation conditions both at a level of mesoclimate and stand microclimate. In years with minus water balance, vegetation growth and distribution as well as development of pests and troublesome forms of insects in the ecosystem of floodplain forests are apparently limited by soil water deficit and by groundwater table under soil surface more than by any other environmental factor. In these situations, the significance of stand microclimate is further increasing, particularly its capacity to partly mitigate stresses induced by drought via temperature and relative air humidity, which play an important role in the development of horizontal precipitation (dew, and etc.).

The results of moisture balance suggest clearly that precipitation cannot be the only source of water for the existence of the floodplain forest ecosystem. Water balance specifies, for example, moisture available for the natural habitat of oak, which according to [10] ranges around $250 \mathrm{~mm}$. Days with water balance of $250 \mathrm{~mm}$ and higher were observed to occur only 5 times during the period of 150 years (1851-2011).

Figure 3 further indicates that a moisture balance forecast may be compared with its actual development. The forecast reveals that the trend of actual (measured) $\mathrm{MB}$ is reaching the values of expected moisture balance of the 2020 time horizon (average of the period 2010-2030). A significant deterioration of MB may be expected in future, its levels falling to deficit values of -56 to $-88 \mathrm{~mm}$, along with a further increase in climate extremities (alternating of surplus and deficit $M B$ values in consequent years). This trend became apparent approximately in 1965.

The expected changes in average monthly air temperatures and monthly precipitation totals were adopted from global circulation models (as a so-called multimodel median of 8 global circulation AR4 models: RCGCM, CNRM, CSIRO, IPSL, MIROC, ECHAM5, MRI, and HADCM3 [11]).

\section{Development of the Groundwater Table in the Confluence Floodplain of the Morava, Dyje, and Kyjovka Rivers}

Detailed measurements of groundwater table (GWT) in the floodplain of the Morava and Dyje Rivers have been taken for 18 years. During this time, extreme states were monitored in the development of groundwater table, caused by flood

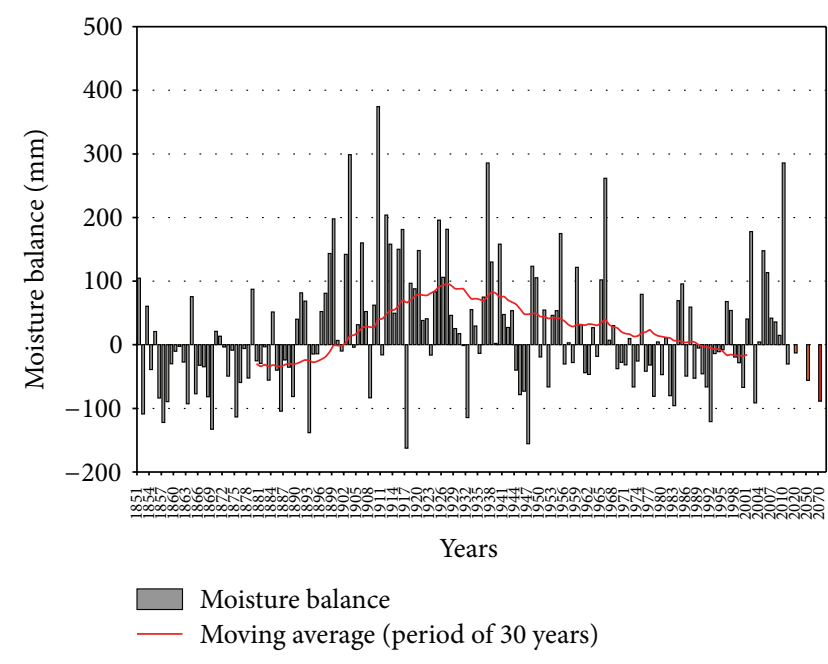

FIGURE 3: Development of moving averages (30 years) of moisture balance in the area of South Moravian floodplain forests in the period of 1851-2011 and prediction of moisture balance for time horizons of 2020, 2050, and 2070 which also represent a 30-year period.

discharges in the core streams of the Morava and Dyje and by the occurrence of a prolonged period of a dry hot climate.

Figure 4 shows the development of average daily groundwater table (GWT) values below the terrain level at the Ranšpurk station standing for the water regime in the region of the Soutok forest district. Development of GWT in this locality significantly differs from the development in the Dyje River floodplain. A different method of hydrotechnical regulations performed in the Morava River (discharge regime is closer to the natural state) and reciprocal mixing of the discharge regimes of the Morava, Dyje, and Kyjovka Rivers entering the confluence floodplain is reflected in the GWT development in the Ranšpurk locality. The water regime is also affected by artificial flooding which has been taking place in this locality since 1996. The lowest GWT level values, reaching the depth of $2,7 \mathrm{~m}$ below the surface (2003), occur in the drier period of the year (from the start of summer until the onset of winter). Maximum GWT level values (apart from the overflowings) at the level of 20 to $60 \mathrm{~cm}$ below the surface occur at the beginning of the growing season.

A characteristic feature of GWT of the confluence floodplain locality is the preservation of typical GWT dynamics. This means that the maximum level of GWT is time dependent on the beginning of the growing season and that the minimum level occurs in the autumn. This feature of the GWT dynamics was attained also at the beginning of the measurements in 1995 (Figure 4). However, conditions of moisture stress (for the longer part of the growing season, the GWT level is below the level of $-1,60 \mathrm{~m}$ ) form in the alluvial plain ecosystem due to GWT "critical level." Owing to increased discharges as a result of a gradual increase in precipitation amounts in the upper reach of the Morava River basin and partly also due to managed artificial flooding, the GWT level is progressively rising to the lower horizons of flood loams of heavier texture. GWT level between 1996 and 
TABLE 2: Long-term monthly precipitation totals $\left(R_{n}\right)$, average monthly air temperatures $\left(T_{n}\right)$, and potential evapotranspiration $\left(\mathrm{EVP}_{n}\right)$ in the area of floodplain forests for the period 1851-2011 (all values are given in $\mathrm{mm}$ ).

\begin{tabular}{lccccccccccccc}
\hline Parameter & $(\mathrm{I})$ & $(\mathrm{II})$ & $(\mathrm{III})$ & $(\mathrm{IV})$ & $(\mathrm{V})$ & $(\mathrm{VI})$ & $(\mathrm{VII})$ & $(\mathrm{VIII})$ & $(\mathrm{IX})$ & $(\mathrm{X})$ & $(\mathrm{XI})$ & $(\mathrm{XII})$ & $(\mathrm{I})-(\mathrm{XII})$ \\
\hline $\mathrm{EVP}_{n}$ & 0.8 & 2.6 & 16.9 & 47.9 & 83.0 & 103.2 & 116.1 & 110.9 & 68.6 & 39.8 & 10.2 & 1.8 & 601.8 \\
$R_{n}$ & 27.6 & 26.0 & 30.3 & 36.7 & 55.5 & 62.8 & 66.1 & 57.7 & 40.6 & 37.9 & 36.9 & 33.1 & 511.4 \\
$T_{n}$ & -1.4 & 0.2 & 4.3 & 9.6 & 14.5 & 17.8 & 19.6 & 18.9 & 15.0 & 9.6 & 4.1 & 0.1 & 9.35 \\
$\mathrm{HP}^{+}$ & 3.3 & 2.1 & 1.1 & 2.6 & 2.6 & 3.8 & 3.2 & 5.8 & 5.8 & 3.9 & 4.9 & 3.1 & 42.2 \\
\hline
\end{tabular}

${ }^{+}$Average values of horizontal precipitation are derived from dew and rime for the period of 1998-2002 from three studied localities of stand microclimate [6].

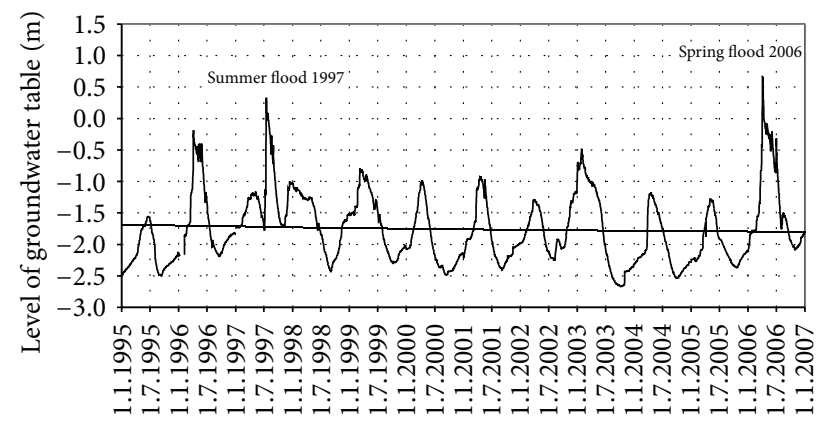

Date

FIGURE 4: Development of daily averages of the groundwater table level 1995-2006 in the monitoring site Ranšpurk in the locality of the forest district Soutok in the confluence floodplain of the Morava and Dyje Rivers. The groundwater table level is expressed by the depth of the water level below the terrain. The trend of groundwater table is fitted with a polynomial of the 2 nd degree.

1997 was quickly rising not only in the spring period but the growing trend could be observed also in the course of the whole year. The reason for this was the predominantly increasing total precipitation in the upper reach of the Morava River basin which first provoked local floods in the Bruntál Region and then, in July 1997, disastrous floods in the entire Morava River catchment area. The July 1997 flood in the locality Ranšpurk culminated in the overflowing of water at the height of $33 \mathrm{~cm}$ above the terrain. Between 1998 and 2002, the GWT level dynamics in the spring period became stabilized around the levels of $-0,50$ to $-1,00 \mathrm{~m}$; in the summer, the GWT level dropped to $-2,20$ to $-2,50 \mathrm{~m}$ below the terrain. The year 2003 presents a certain exception because the Morava R. first showed a more distinct discharge growth from the melting snow in the upper reach of the river's catchment area. In the dry and extremely hot climate during the summer, the favourable GWT level (over $-1,60 \mathrm{~m}$ ) could be maintained by means of artificial flooding only until June. In August and September, the GWT level rapidly dropped to the absolute minimum levels of $-2,70 \mathrm{~m}$. In 2004 and 2005, the GWT dynamics started improving slightly thanks to the growing spring discharges from the thawing snow pack. This process culminated in the second largest flood registered in the period of 1995-2006 in the Morava River basin. The spring flood of 2006 reached its peak in the locality of Ranšpurk at the turn of March and April, with flood water overflowing at the maximum level of $67 \mathrm{~cm}$ above the terrain.

The specific character of soil moisture regime in the natural conditions of floodplain forest ecosystems is conditioned by the interrelations and effect of five crucial factors. It primarily encompasses the diverse soil conditions of alluvial sediments consisting of a variety of soil textures, ranging from light sandy soils to heavy clay soils, all in various, usually, stratified combinations. The subsoil of these soils usually contains gravel depositions of varying depth. The second factor represents the hydrological conditions of rivers, such as the flow intensity and dynamics throughout the year. The third factor includes local climatic conditions in general, particularly atmospheric precipitation, its yields, and intensity. The fourth factor of no lesser importance with respect to assessing the soil moisture regime of a given place or site is the terrain microrelief, which significantly affects the soil moisture regime. The fifth factor encompasses the vegetation cover, mostly in the form of floodplain forests and meadows, sometimes fields.

As for the forest floor heterogeneity, we can remark that the main factor is the species composition of forest stands, which is furthermore emphasized by the creation of pure stands as a result of clear-felling forest regeneration. The importance of differences, particularly between stands of oak and ash, is also demonstrated by the dynamics of decomposition processes during the year, as determined by the method of litter bags. It has been found that the forest decomposition of litter in a floodplain forest occurs, generally, in ash and hornbeam stands during the winter season [12].

Following the above-mentioned facts it is evident that in the course of assessing the hydrological and soil moisture regimes in floodplain ecosystems various situations may arise based on the listed factors.

Prax et al. [13] state that the primary source of groundwater in the Morava River floodplain is river water seeping through the highly permeable gravel-sandy subsoil. Precipitation also plays a certain role, mostly by positively affecting the moisture balance of soil profiles, namely, their surface horizons. This is closely related to the influence of water brought in by the restoration channels. Growth-ring analyses of the narrow-leaved ash radial increment revealed that every sudden and long-term change in the groundwater table regime results in a decreased radial increment. The period which ash stands require to adjust to changed natural conditions takes approximately from seven to ten years [12]. 


\section{Ecological Response to Changes in Water Regime and Restoration of the Floodplain Forest Environment}

A team of the Department of Forest Ecology of Mendel University in Brno studied this issue systematically in the 1990s. The obtained results were summarized in a publication [14, 15]. We present the following conclusions reached by the team.

The primary dominant species of the tree layer, such as the pedunculate oak (Quercus robur L.) and ash (Fraximus excelsior L.; Fraximus angustifolia Vahl), did not show a significant response to changes in water regime.

The layer of shrubs and young trees with prevailing Cornus sanguinea L. responded to a change in the water regime by a decrease in the leaf area index.

The herb layer responded to changes in water regime significantly, displaying a 60-70\% decrease in biomass within ten years. Apart from this, a decline in the species diversity of the herb layer was monitored at some localities.

The trend of changes in the composition of herb layer communities is shifting towards drier communities.

During the times of regular floods, native grassland ecosystems worked as important producers and fulfilled important ecological and economic functions. After floods had been eliminated, vast areas of native grasslands were ploughed up. The rich supplies of humus and nitrogen generated by the grassland ecosystems had a positive effect on farm production at the initial stages following the ploughing-up.

Apart from changes in the water regime caused by the elimination of floods, climate change must be taken into consideration as well. The climate in the South Moravian region in the period following the flood control measures is going through a warm and dry period compared with the longterm means for annual temperature $\left(9.0^{\circ} \mathrm{C}\right.$; $9.3^{\circ} \mathrm{C}$ in $1973-$ 1982 ) and annual precipitation (524 mm; 453 in 1973-1982). In the period following the flood control measures there have been annual precipitation deficits, most frequently in August and September [15].

In the late 1980s, foresters were the first to realize the potentially disastrous effects of the flood control measures on floodplain forests. In the 1990s, in collaboration with hydrologists and other experts they prepared projects aimed at bringing water back inside the floodplain forests. In 19911999 a complex network of water channels, sluice gates, culverts, and small dams was built, allowing the control of water in vernal and permanent pools, as well as the groundwater table and its natural fluctuation in the vegetation season. After many years, wetland biotopes with permanent or periodic inundation reappeared in the forests. Forest stand vitality improved significantly as well. This influence is spatially limited to the distance of approximately $10-20 \mathrm{~m}$, where it combines with groundwater table affected by the primary recipient, while in the spring time the channels function as drainage elements (Figures 5, 6, and 7).

However, it was generally noted that the restoration channel network displays a relatively low functionality. The preparation and construction of three Nové Mlýny Water
Reservoirs provoked numerous discussions. The aim of this project was to protect the surrounding landscape from floods and to allow utilization of water supplies in dry periods of the year for irrigation of farm crops. Foresters took advantage of this possibility in the course of the implemented restoration projects of large-scale artificial inundation which, however, was gradually abandoned.

\section{South Moravian Floodplain Forest Management}

It is rather difficult to set an exact time which may separate a mere utilization of floodplain forests and their systematic management. Nožička [16] notes that planned forest management was introduced at the Liechtenstein estates in the 1760s. The rotation period for coppice forests was set at 20 to 40 years. Introduction of exotic tree species from North America dates back to 1799. According to Vybíral [17], it is safe to say that intensive cultivation of floodplain forests starts at the beginning of the 19th century. Last remnants of native natural forests disappeared, followed by a period of transformation of the originally predominantly softwood floodplain forests into cultivated forests with dominant longlived, broad-leaf species, the so-called hardwood floodplain forests. The Liechtenstein foresters were aware of the high production capacity of floodplain sites in Slavonia, where original complexes of floodplain oak forests with growing stock exceeding $1,000 \mathrm{~m}^{3}$ per hectare could still be found. In the late 19th and early 20th centuries, up to 50 tons of Slavonic acorns was therefore imported to South Moravia every year.

Softwood floodplain forests with low representation of oak began to be restored on large clear-cut areas, and between the rows of regenerated trees farm crops were grown [17]. This has resulted in the following species composition of most stands of South Moravian floodplain forests: pedunculate oak (Quercus robur L.) 41\%, narrow-leaved ash (Fraximus excelsior L.; Fraximus angustifolia Vahl) 29\%, poplars (usually cultivars) 13\%, willow (Salix alba L.) 4\%, maple (Acer campestre L.) 3\%, hornbeam (Carpinus betulus L.) 2\%, linden (Tilia cordata Mill) 2\%, and other deciduous species and pine $3 \%$.

The present species composition of dominant tree species in floodplain forests does not correspond with the natural site composition. Floodplain forests with dominant hardwood tree species (pedunculate oak/Quercus robur L./, narrowleaved ash/Fraximus excelsior L.; Fraximus angustifolia Vahl) evolved as a result of long-term, systematic management measures. Traditionally, floodplain forests regenerated on areas of up to several dozen hectares, with the area of exploited clearcuts being gradually limited to 5 ha. At present the Forest Act allows floodplain forest clearcuts of up to 2 ha. Utilization of pedunculate oak regeneration appears to be optimal, but it faces several problems. The crucial issue preventing the dominant use of the said method is a shortage of oak forests with suitable lower storey as well as prepared stands (without a high representation of ash). Another limitation is the fact that floodplain oak stands have very low production. The year 1999 proved to be an exception, as oaks had not produced virtually any mast for 


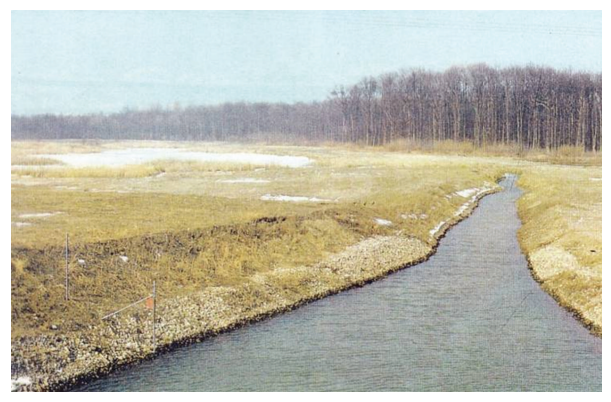

(a)

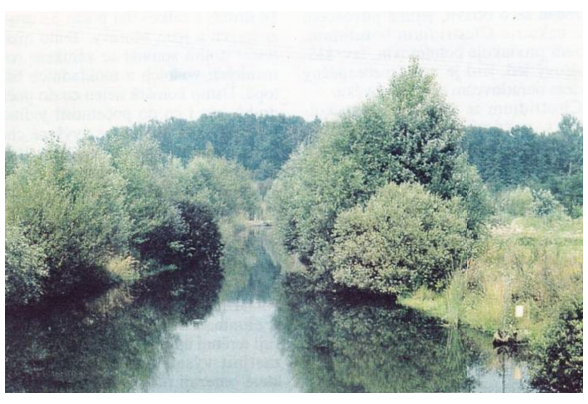

(b)

FIGURE 5: Wetland restoration: tree vegetation formed during the period of 1982-1990 (South Moravia).

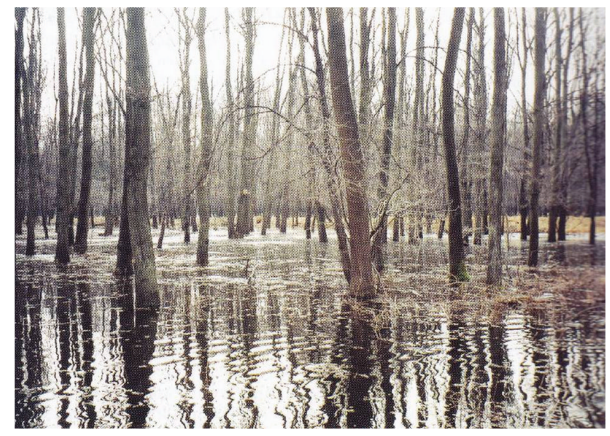

FIGURE 6: Large-scale artificial inundation.

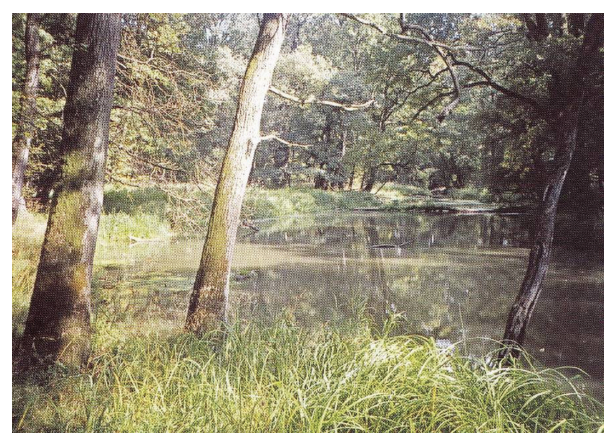

FIGURE 7: Water pools restored by means of channels.

over 30 years. The question why it was the case is subject to further study. For the time being, the only tested and so far proved hypothesis states that pedunculate oaks growing in the existing stands in the Czech Republic have very small crowns, masting very little or not at all, while stands of oak trees with large crowns growing in two-storey stands mast significantly more. This can be observed mainly abroad (Croatia, France), where natural regeneration of this tree species is commonly adopted. Low seed yields and massive damage caused by rodents also pose threats. Nevertheless, should a strong mast year of pedunculate oak (Quercus robur L.) come, it is advantageous to subject suitable stands to natural regeneration (the best method being scarification of the soil surface prior to regeneration), whereby game, rodent,

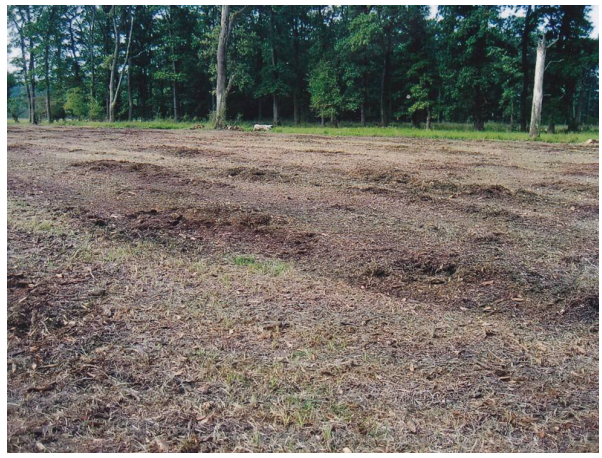

FIGURE 8: Site prepared for artificial regeneration.

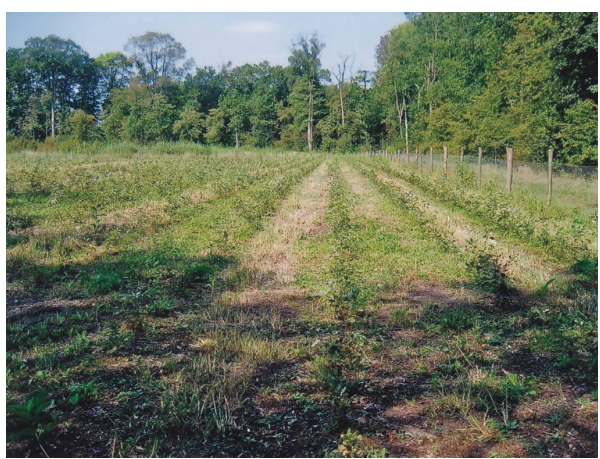

FIGURE 9: Artificial regeneration of oak (Quercus robur L.).

and weed control are required. A successfully naturally regenerated stand encompasses a minimum of 3 seedlings per $1 \mathrm{~m}^{2}$ after the first year of regeneration (Figures 8 and 9).

Starting from 1998, artificial stand regeneration is done on sites prepared by wood chippers.

(i) In winter or spring, wood chippers processing brushwood into coarse chips are deployed in clearcuts with brushwood left after harvesting.

(ii) The chips are left on the site where they work as a mulch layer and partly prevent weed growth.

(iii) At the end of the vegetation season (August, September) chemical weed control is applied from tractormounted sprayer. 
(iv) Mechanized sowing or planting is done ideally in autumn months (November, December) or in early spring.

Apart from artificial regeneration of oak (Quercus robur L.), a similar method is applied, for example, in regeneration of the black walnut (Juglans nigra L.) which at present covers over 350 ha. Additionally, artificial regeneration of "classical" forest clones of hybrid poplars and cherry trees (Prunus avium $L_{\text {. }}$ ) is underway as well.

\section{Conclusion}

It may be concluded that South Moravian floodplain forests have deservedly become the focus of keen interest of foresters, research institutions, nature conservationists, and international organizations alike. July 2003 marked the designation of the Lower Morava Biosphere Reserve by UNESCO in Paris, which encompassed virtually all important floodplain forests along the lower reaches of the Morava and Dyje Rivers and made them part of the World Network of Biosphere Reserves. South Moravian floodplain forests underwent major changes of their natural conditions in Early Middle Ages as well as changes brought about by foresters' efforts to cultivate high-quality production forests in the area. Regulation of the Morava and Dyje Rivers in the 20th century and the consequent changes in groundwater table also made a major impact on the condition of the floodplain forests. The implementation of restoration projects is therefore driven by efforts to enhance the forest environment and thus sustain both the production and nonproduction functions of the South Moravian floodplain forests.

\section{Acknowledgments}

The paper was prepared under the financial support of the NAZV QJ1220033 Research Project "Optimization of Water Regime in the Model Area of the Morava River Alluvium" and within the Joint Project "The Functioning of Floodplain Forest Ecosystem in the Sava and Drava (Croatia) and Morava and Dyje (Czech Republic) Rivers Watershed under Changed Environment, Catastrophic Flooding and other Anthropogenic Impact."

\section{References}

[1] E. Klimo, H. Hager, S. Matič, I. Anič, and J. Kulhavý, Floodplain Forests of the Temperate Zone of Europe, Lesnická Práce, Kostelec nad Černými lesy, 2008.

[2] Z. Neuhauslova, Map of Potential Vegetation of the Czech Republic, Academia Praha, 1998.

[3] P. Havlíček, "Geology of the dyje and morava confluence," in Floodplain Forests of the Morava and Dyje Floodplain, $\mathrm{H}$. Kordiovský, Ed., pp. 12-19, Moraviapress Břeclav, 2011.

[4] L. Poláček, "The prehistory and history of the river valley landscape," in Morava River Floodplain Meadows-Importance, Restoration and Management, J. Šeffer and V. Stanová, Eds., pp. 25-36, DAPHNE, Bratislava, Slovakia, 1999.

[5] H. Kilianová, Assessment of changes in forest geobiocenoses in the Morava River floodplain during the $19^{\text {th }}$ and $20^{\text {th }}$ centuries [Ph.D. dissertation], Olomouc, Czech Republic, 2001.
[6] P. Hadaš, "Temperature and humidity conditions of the floodplain forest with respect to stand microclimate and mesoclimate," Ekológia, vol. 22, supplement 3, pp. 19-46, 2003.

[7] P. Prax, "The hydrophysiological properties of the soil and changes in them," in Floodplain Forest Ecosystem II. After Water Management Meausures, M. Penka, M. Vyskot, E. Klimo, and F. Vašíček, Eds., pp. 145-168, Amsterdam coed. Academia, Prague, Czech Republic, 1991.

[8] M. Možný, "Potential evapotranspiration as an important agroclimatic characteristic," Meteorologické Zprávy, vol. 46, no. 5, pp. 152-156, 1993 (Czech).

[9] W. Mottl, "Abschätzung der potentiellen Evapotranspiration aus Klimadaten und Vergleich verschiedener Berechnungsmethoden," Österreichische Wasserwirtschaft, vol. 35, no. 9/10, pp. 247254, 1983.

[10] B. Vinš et al., "Impacts of a possible climatic change on forests in the Czech Republic-Territorial study of climate change" (Czech), National Climatic Programme of Czech Republic. Element, 19, 2, ČHMÚ Praha, pages 135, 1996.

[11] J. Kalvová, E. Holtanová, M. Motl, J. Mikšovský, P. Pišoft, and A. Raidl, "Odhad rozsahu změn klimatu České republiky pro tř̌i časová období 21 . Století na základě výstupů AR4 modelů (Estimated Scope of Climate Change in the Czech Republic for Three Time Periods in the $21^{\text {st }}$ Century Based on AR4 Model Outputs)," Meteorologické Zprávy, vol. 2, no. 63, pp. 57-66, 2010.

[12] E. Klimo, V. Hybler, H. Lorencová, and J. Štykar, "The heterogeneity of soil properties and biodiversity in floodplain forests of southern moravia in natural conditions and under antropogenic impacts," Ekologia Bratislava, vol. 30, no. 3, pp. 296-314, 2011.

[13] P. Prax, A. Prax, M. Kloupar, J. Heteša, and I. Sukop, “Optimization of the floodplain ecosystem hydrological regime following anthropogenic interference and its inclusion in the tvrdonice forest district management plan," Grantová služba LČR, Teplice. Závěrečná zpráva, pages 27, 2005.

[14] M. Penka, M. Vyskot, E. Klimo, and F. Vašíček, Floodplain Forets Ecosystem II. After Water Management Meausures, Elsevier, Prague, Czech Republic, 1991.

[15] F. Vašíček, "Changes in the structure and biomass of the herb layer under the condition of a medium moisture gradient," in Floodplain Forest Ecosystem II. After Water Management Meausures, M. Penka, M. Vyskot, E. Klimo, and F. Vašíček, Eds., pp. 197-242, Amsterdam coed. Academia, Prague, Czech Republic, 1991.

[16] J. Nožička, An Outline of the Evolution of our Forests, Praha, Czech Republic, 1957.

[17] J. Vybíral, "Role of foresters in the floodplain landscape," in Floodplain Forests of the Morava and Dyje Floodplain, H. Kordiovský, Ed., pp. 163-172, Moraviapress, Břeclav, Czech Republic, 2004. 

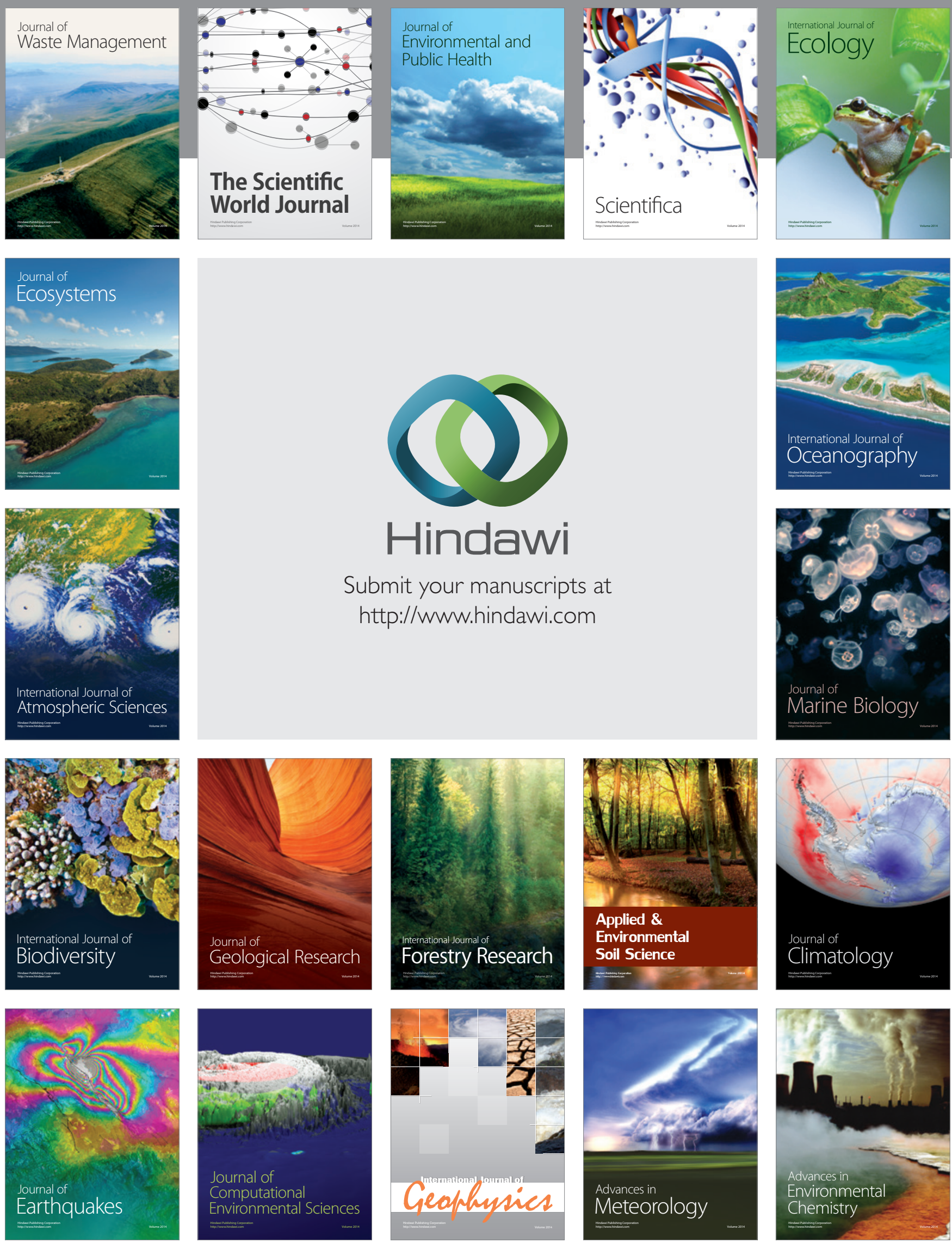